\title{
Knowledge Management and Czech Self- Governments: Empirical Investigations into the Application of Knowledge Management to Public Administration in the Czech Republic
}

David Špaček ${ }^{1}$, Eva Gatarik ${ }^{2}$

\begin{abstract}
Although knowledge management has become the subject of an enormous quantity of articles and books in recent times, certain more problematic aspects of it remain neglected. Firstly, literature addressing knowledge management concentrates almost exclusively on business organizations and fails to provide details or recommendations adequate to effective application within the sphere of public administration. This holds especially true for Czech academic literature. Secondly, despite a reasonable number of articles on knowledge management in scientific journals, information about perceptions of knowledge-management activities, procedures and tools within organizations lacks detail. The purpose of this article is to investigate and summarize the activities, procedures and tools in use for dealing with knowledge within Czech self-governments and to discuss the main empirical findings. Although the quantitative survey herein does not provide fully representative data, it is still in a position to indicate that knowledge management in Czech public administration tends to be underdeveloped as well as undervalued.
\end{abstract}

\section{Keywords:}

knowledge management, public administration, public management

1 Assistant Professor, Faculty of Economics and Administration, Masaryk University, Brno, Czech Republic.

2 Assistant Professor, Faculty of Economics and Administration, Masaryk University, Brno, Czech Republic. 


\section{Introduction}

It has been authoritatively maintained for some time that knowledge management (KM) may increase the capacity for innovation and facilitate responsiveness (Alavi and Leidner 2001). However, even in 2015 Bolisani and Handzic (2015) pointed out that, despite its 20 years of history and increasing importance in academia, KM still suffers, as do many other "new areas", from a recognition problem (Spender 2015). Handzic (2015) adds that there is no general agreement about the precise meaning and relevance of knowledge management and, furthermore, there is no clear differentiation between knowledge management and fields such as organizational learning and intellectual capital.

The available academic literature clearly shows that KM has attracted burgeoning international attention in the past few decades. Although this literature is not unified when it addresses KM as a concept, it is far more united in considering KM as a more-or-less similar suite of main processes when explaining its implementation as a set of techniques to identify, capture, store, share and apply knowledge. It has also come to discuss the barriers to KM that partly originate in the characteristics of tacit knowledge, as well as in the mindsets of employees, together with difficulties generated by the rapidly changing cultures of organizations.

For all the growth in KM literature, it is noteworthy that it deals primarily with recommendations and practices within private organizations rather than with directions required if $\mathrm{KM}$ is to be implemented in both public-administration and public-sector organizations (see also Plaček et al. 2016b), even though the public sector is widely accepted as different from the private sector and certain features unique to it lead to the adaptation of KM practices being considered beneficial (Farzin et al. 2014). Nevertheless, the key elements - sometimes "components" - of KM frameworks at the operational level appear to be very similar to those discussed in literature focusing on the private sector - people, processes and technologies (sometimes content is added, e.g. Hasan 2004: smart-city literature emphasizes the importance of work with technology factors, institutional factors and human factors, e.g. Nam and Pardo 2011).

In some countries (for example Australia and its AS 5037-2005, or Knowledge Management PAS 2001 of the British Standards Institution), specific KM standards have been worked up in order to serve as guidelines for the implementation of KM in public organizations where potential for improvements in accountability, transparency, inclusiveness (and responsiveness) by more knowledge-intensive activities and processes has been recognized (e.g. Ferguson 2006; Burford and Ferguson 2009; Hasan 2004; Nielsen 2014). KM practices are also context-specific (Farzin et al. 2014; Gatarik and Born 2012; Gatarik 2014; Gatarik and Born 2015; Ammons and Roenigk 2015; Martin and Spano 2015; Hammerschmid et al. 2013), and a considerable body of literature has approached the specifics and issues of public- 
administration reforms in transitional countries from Central and Eastern Europe (among the most recent ones, see, for example, Klimovský et al. 2014; Plaček et al. 2015; Plaček et al. 2016a; Plaček et al. 2016b; Němec et al. 2015a; Němec et al. 2015b; Matejova et al. 2015).

In the Czech Republic, knowledge management, both as an academic and a practical discipline, is somewhat underdeveloped if one considers the available literature relevant to public administration as well as research involving public management. The aim of this contribution is to summarize selected findings from a survey which concentrated on particular aspects of KM preconditions and processes in semi-autonomous local authorities - "self-governments" - in the Czech Republic, those of municipalities and regions or, more clearly, on their primary executive bodies - their offices. The survey was built on the assumption that, although KM is not immediately evident in terms of academic books and guidelines, there always exists something of it in the managerial practices of public authorities - or, as the international literature sometimes points out, the concept of KM is nothing new and has been in practice for a long time, mostly in an informal manner, and organizations have always used KM practices (in various incarnations) to make decisions and to produce goods and services, although not in a deliberate and systematic manner (Cong and Pandya 2003).

\section{Methodology}

To date, KM investigation in the Czech Republic has especially concerned itself with the potential of KM awareness and practices for private businesses. The concept of KM as applicable to public administration and the public sector is quite new to research in the country. Available outputs indicate that KM research has been somewhat ICT-focused (technology-oriented). Among knowledge creation tools, benchmarking in particular has been given a relatively higher degree of attention in public-management research in the country, perhaps a consequence of its degree of acceptance in comparison to other tools and methods linked to quality management in Czech public administration (see Špaček 2015; Špaček 2016).

A questionnaire survey aimed at Czech self-governments was prepared, in accordance with the existing KM literature, within the research framework of the TAČR (Knowledge Management in Local and Regional Development) project. Input was obtained through semi-structured interviews with a number of respondents from municipal and regional offices. The survey design reflected process-oriented definitions of KM which explain it through the lens of KM processes in organizations (see, e.g., Cong and Pandya 2003). The questionnaire combined open-ended questions and enquiries into the perceptions of respondents from municipal and regional self-governments. Particular attention was paid to processes usually linked to KM: identification, capture, storage and sharing. It also included questions con- 
cerning what might be called the "general management environment" (or "strategic aspects" in the terms used by Edwards 2015), KM-supporting tools (people and technological aspects), and barriers.

We addressed the questionnaires to respondents from the following categories of Czech self-governments:

- all 2,903 municipalities with fewer than 2,000 inhabitants from six regions (Jihomoravský, Královehradecký, Moravskoslezský, Olomoucký, Středočeský and Ústecký, constituting $52 \%$ of the country);

- all 413 larger municipalities from these six regions;

- all municipalities officially designated type II (393) and III (205) (in Czech they are termed obce s poverérným úřadem [literally "administrative unit with authorized office"] and obce s rozšířenou pưsobností ["administrative unit with extended powers"] and are distinguished as municipalities by their degrees of responsibility for state administration activities);

- all 138 municipalities with more than 10,000 inhabitants;

- all 14 regional offices.

The database of contacts held by the Ministry of Regional Development, which contains general contact e-mails (at e-registry offices or with a mayor), was used for the municipalities. For the regions, the questionnaire was addressed to all employees in managerial posts (to the executives of regional offices and heads of individual departments and sub-departments). A slightly different form of the questionnaire was used for the survey directed at municipalities with fewer than 2,000 inhabitants, the better to accommodate their own specifics. A more comprehensive form was sent to representatives of larger self-governments.

The questionnaire survey was carried out between 10 March and 13 April 2016. Although representatives had been asked twice to fill in our questionnaire before the survey closed, the return rate of the questionnaires did not exceed $5 \%$, consisting of:

- 142 questionnaires from respondents from municipalities with fewer than 2,000 inhabitants (hereinafter "small municipalities" or "municipalities $<2,000$ "); $16 \%$ of these respondents were employees of municipal offices, $84 \%$ were mayors, of whom more than $70 \%$ had worked for the municipality more than five years and had been released from their responsibilities by their former employers - they are described as uvolnèný ["informal"] in Czech. The structure of respondents is summarized in Table 1. It should be noted that, in the Czech Republic, the position and title of "mayor" extends all the way to village level; it might be described as "elected chief administrative officer". 
Table 1

Structure of respondents from small municipalities (size of municipality)

\begin{tabular}{|l|c|c|}
\hline Size of municipality (inhabitants) & Questionnaires obtained & \% \\
\hline up to 199 & 25 & 17.6 \\
\hline $200-499$ & 43 & 30.3 \\
\hline $500-999$ & 41 & 28.9 \\
\hline $1,000-1,499$ & 23 & 16.2 \\
\hline $1,500-2,000$ & 10 & 7.0 \\
\hline Total & $\mathbf{1 4 2}$ & $\mathbf{1 0 0 . 0}$ \\
\hline
\end{tabular}

Source: own research

- 65 questionnaires from respondents from larger municipalities (those with more than 2,000 inhabitants, hereinafter "municipalities 2000+"); more than $60 \%$ of them had worked for the municipality for more than ten years. Their structure is summarized in Tables 2 and 3.

Table 2

Structure of respondents from larger municipalities (size of municipality)

\begin{tabular}{|l|c|c|}
\hline Size of municipality (inhabitants) & Questionnaires obtained & \% \\
\hline $2,001-10,000$ & 29 & 44.6 \\
\hline $10,001-20,000$ & 3 & 4.6 \\
\hline $20,001-50,000$ & 3 & 4.6 \\
\hline $50,001-150,000$ & 9 & 13.8 \\
\hline 150,001 and over & 21 & 32.3 \\
\hline Total & $\mathbf{6 5}$ & $\mathbf{1 0 0 . 0}$ \\
\hline
\end{tabular}

Source: own research 
Table 3

Structure of respondents from larger municipalities (job position of the respondent)

\begin{tabular}{|l|l|l|}
\hline \multicolumn{1}{|c|}{ Job position of the respondent } & $\begin{array}{l}\text { Questionnaires } \\
\text { obtained }\end{array}$ & \multicolumn{1}{c|}{$\%$} \\
\hline Regular employee (referent ["official"]) & 14 & 21.5 \\
\hline $\begin{array}{l}\text { Mayor (starosta/primátor ["mayor/city or village } \\
\text { manager"]) }\end{array}$ & 8 & 12.3 \\
\hline Secretary (tajemník [secretary to an organization]) & 14 & 21.5 \\
\hline Head of department (vedoucí odboru) & 17 & 26.2 \\
\hline Head of a subunit of a department (vedoucí oddělení) & 12 & 18.5 \\
\hline Total & $\mathbf{6 5}$ & $\mathbf{1 0 0 . 0}$ \\
\hline
\end{tabular}

Source: own research

- 71 questionnaires from respondents from regional offices; there were respondents from all 14 regions and more than $66 \%$ of them had worked for the region for more than 10 years. Their structure is summarized in Table 4.

Table 4

Structure of respondents from regional offices (job position of the respondent)

\begin{tabular}{|l|c|c|}
\hline \multicolumn{1}{|c|}{ Position } & $\mathbf{n}$ & $\mathbf{\%}$ \\
\hline Regular employee (referent) & 16 & 22.5 \\
\hline Head of office (ředitel ["manager"]) & 2 & 2.8 \\
\hline Head of department (vedoucí odboru) & 18 & 25.4 \\
\hline Head of a subunit of a department (vedoucí oddělení) & 35 & 49.3 \\
\hline Total & $\mathbf{7 1}$ & $\mathbf{1 0 0 . 0}$ \\
\hline
\end{tabular}

Source: own research

If a respondent was a regular employee or a head of department or sub-department, they were responsible particularly for tasks in the areas that appear in Table 5 (because the administrative offices of small municipalities have less complex structures, these details were omitted from their questionnaires).

We guaranteed anonymity to all respondents from regional offices, and this was also reflected in the questionnaire design. The structure of respondents in terms of individual regions and other specifics cannot therefore be described. 
Table 5

Structure of respondents (areas of responsibility)

\begin{tabular}{|l|c|l|c|}
\hline \multicolumn{1}{|c|}{ Municipalities 2000+ } & n & \multicolumn{1}{c|}{ Regions } & n \\
\hline property administration & 13 & economy and finance & 24 \\
\hline office of the secretary & 13 & regional development & 22 \\
\hline economy and finance & 11 & investments & 16 \\
\hline human resources & 11 & property administration & 15 \\
\hline $\begin{array}{l}\text { development of the } \\
\text { municipality }\end{array}$ & 10 & culture, education and sport & 13 \\
\hline internal affairs & 10 & environment & 8 \\
\hline transport and roads & 9 & building construction office & 8 \\
\hline Environment & 9 & office & 8 \\
\hline IT & 9 & internal affairs & 7 \\
\hline culture, education and sport & 7 & healthcare & 6 \\
\hline internal audit & 7 & social services & 6 \\
\hline investments & 6 & legal services & 5 \\
\hline legal services & 6 & IT & 5 \\
\hline social services & 4 & transport and roads & 4 \\
\hline trades licensing office & 3 & trades licensing office & 4 \\
\hline building construction office & 2 & internal audit & 3 \\
\hline
\end{tabular}

Source: own research.

\section{Results}

The number of questionnaires gathered does not allow for conclusive interpretations of findings. However, the indications that follow may well generate hypotheses and directions for future research.

Selected findings on the general management environment and tools used for knowledge identification are summarized in Table 6 . This clearly indicates that the larger the office, the larger the group of surveyed instruments. However, even the larger municipalities may not always have a thematic strategy that might bring general strategic plans into operation. They may also fail to use benchmarking to learn from similar authorities. Further, although the respondents claimed that their authority works with community planning, their responses indicate that quality of life and citizen/customer satisfaction were only seldom assessed at least once every two years, which goes against the philosophy of community planning. Other answers indicate that long-term plans are not worked up into a set of more specific aims in any of the municipalities, regardless of size. This may be one reason why 
similar percentages of respondents stated that long-term plans were not evaluated at least once every two years. Although the larger offices work with job descriptions, these outlines contain actual specifications of knowledge required according to only $56 \%$ of respondents from the larger municipalities (regional offices returned a corresponding figure of $85 \%$ ). Only $32 \%$ of respondents from larger municipalities and $46 \%$ of respondents from regional offices stated that such descriptions also contained descriptions of their working relationships with other employees within the office, something that may well hamper knowledge-sharing.

\section{Table 6}

General management environment - overall selected findings

\begin{tabular}{|l|c|c|c|}
\hline \multicolumn{1}{|c|}{ Instrument } & $\begin{array}{c}\text { Municipalities } \\
\mathbf{2 0 0 0}\end{array}$ & $\begin{array}{c}\text { Municipalities } \\
\mathbf{2 0 0 0 +}\end{array}$ & Regions \\
\hline Strategic plan of development & $79 \%$ & $82 \%$ & $94 \%$ \\
\hline Thematic strategy for development & $39 \%$ & $69 \%$ & $96 \%$ \\
\hline Programmef/strategy of development & $57 \%$ & $58 \%$ & $90 \%$ \\
\hline Community planning & $50 \%$ & $69 \%$ & $71 \%$ \\
\hline Budgetary plan & $96 \%$ & $92 \%$ & $96 \%$ \\
\hline Municipal office development plans & $22 \%$ & $44 \%$ & $91 \%$ \\
\hline Assessment of client satisfaction & $12 \%$ & $37 \%$ & $68 \%$ \\
\hline Assessment of quality of life & $18 \%$ & $39 \%$ & $58 \%$ \\
\hline Assessment of employee satisfaction & $13 \%$ & $54 \%$ & $75 \%$ \\
\hline Employees evaluation system & $26 \%$ & $69 \%$ & $85 \%$ \\
\hline Description of job positions & $13 \%$ & $92 \%$ & $99 \%$ \\
\hline Description of working procedures & $34 \%$ & $55 \%$ & $79 \%$ \\
\hline Educational needs analysis & $24 \%$ & $61 \%$ & $82 \%$ \\
\hline Mapping and improvement of processes & $18 \%$ & $44 \%$ & $81 \%$ \\
\hline Process management & $19 \%$ & $47 \%$ & $83 \%$ \\
\hline Employees performance audit & $10 \%$ & $29 \%$ & $52 \%$ \\
\hline Benchmarking with other offices & $18 \%$ & $39 \%$ & $87 \%$ \\
\hline CAF & $1 \%$ & $12 \%$ & $64 \%$ \\
\hline EFQM & $1 \%$ & $5 \%$ & $40 \%$ \\
\hline Certification according to ISO 9000 & $1 \%$ & $14 \%$ & $48 \%$ \\
\hline Certification according to ISO 27000 & $1 \%$ & $14 \%$ & $26 \%$ \\
\hline CSR & $10 \%$ & $9 \%$ & $50 \%$ \\
\hline Local agenda 21 & $11 \%$ & $30 \%$ & $54 \%$ \\
\hline So & & & \\
\hline
\end{tabular}

Source: own research.

Findings on KM enablers (and potential barriers) are summarized in Table 7. 
Table 7

Barriers arising out of neglecting KM (KM disablers)

\begin{tabular}{|l|l|l|l|}
\hline & $\begin{array}{c}\text { Municipalities } \\
<\mathbf{2 0 0 0}\end{array}$ & $\begin{array}{c}\text { Municipalities } \\
\mathbf{2 0 0 0 +}\end{array}$ & Regions \\
\hline $\begin{array}{l}\text { Our office does not have a clear KM } \\
\text { strategy. }\end{array}$ & $59 \%$ & $67 \%$ & $35 \%$ \\
\hline $\begin{array}{l}\text { Our office does not have a written KM } \\
\text { strategy. }\end{array}$ & - & $70 \%$ & $43 \%$ \\
\hline $\begin{array}{l}\text { Creation of a functional KM system is not } \\
\text { among our current priorities. }\end{array}$ & $56 \%$ & $67 \%$ & $37 \%$ \\
\hline $\begin{array}{l}\text { We do not have sufficient internal norms for } \\
\text { KM. }\end{array}$ & $55 \%$ & $56 \%$ & $39 \%$ \\
\hline $\begin{array}{l}\text { Current KM practices are not evaluated } \\
\text { sufficiently. }\end{array}$ & $56 \%$ & $66 \%$ & $48 \%$ \\
\hline $\begin{array}{l}\text { KM does not work and management does } \\
\text { not think change is required. }\end{array}$ & $38 \%$ & $43 \%$ & $39 \%$ \\
\hline $\begin{array}{l}\text { We do not work with KM because it is } \\
\text { perceived as a useless time burden. }\end{array}$ & $49 \%$ & $47 \%$ & $31 \%$ \\
\hline
\end{tabular}

Source: own research

Table 7 indicates that Czech municipalities do not work with clear KM strategies. The reasons also appear in the table - the creation of a functional KM system is not often among immediate priorities, and current KM practices are not evaluated sufficiently (perhaps depending on perceptions/understanding of KM). A relatively high percentage of respondents from larger authorities maintained that KM is perceived as useless and a time-burden, although respondents stated that the managers of their offices have sufficient knowledge of the possibilities and instruments of KM. Regular employees (practitioners) were more critical than their superiors in their responses to certain questions.

The findings on selected aspects of the ways in which KM enablers support instruments and tools related to primary KM processes such as identification, capture, storage and sharing are summarized in Table 8. 


\section{Table 8}

Basic KM tools and instruments - overall selected findings

\begin{tabular}{|c|c|c|c|}
\hline & $\begin{array}{l}\text { Municipalities } \\
<2000\end{array}$ & $\begin{array}{c}\text { Municipalities } \\
2000+\end{array}$ & Regions \\
\hline \multicolumn{4}{|l|}{ Knowledge identification } \\
\hline $\begin{array}{l}\text { Requirements of job positions are clearly } \\
\text { defined. }\end{array}$ & $85 \%$ & $86 \%$ & $93 \%$ \\
\hline $\begin{array}{l}\text { Executive heads/managers evaluate } \\
\text { activities of their departments regularly. }\end{array}$ & $54 \%$ & $71 \%$ & $80 \%$ \\
\hline $\begin{array}{l}\text { Evaluation of employees by their superiors } \\
\text { is based on clear and known/shared criteria. }\end{array}$ & $57 \%$ & $65 \%$ & $75 \%$ \\
\hline $\begin{array}{l}\text { Employee evaluation is always reflected in } \\
\text { plans for further training. }\end{array}$ & $47 \%$ & $58 \%$ & $72 \%$ \\
\hline $\begin{array}{l}\text { Required knowledge is assessed only in } \\
\text { certain departments. }\end{array}$ & - & $39 \%$ & $31 \%$ \\
\hline \multicolumn{4}{|l|}{ Knowledge capture and storage } \\
\hline $\begin{array}{l}\text { Necessary knowledge is captured in a } \\
\text { systematic way in all departments in order } \\
\text { not to lose it. }\end{array}$ & $53 \%$ & $55 \%$ & $61 \%$ \\
\hline $\begin{array}{l}\text { We have a database of key employee } \\
\text { knowledge. }\end{array}$ & $26 \%$ & $25 \%$ & $41 \%$ \\
\hline $\begin{array}{l}\text { When an employee is leaving, we use } \\
\text { a completion form that also includes } \\
\text { a description of tasks in process and } \\
\text { necessary knowledge for their completion. }\end{array}$ & $51 \%$ & $57 \%$ & $59 \%$ \\
\hline $\begin{array}{l}\text { When an employee successfully completes } \\
\text { important training, he/she always submits a } \\
\text { report on the benefits of that training. }\end{array}$ & $26 \%$ & $35 \%$ & $55 \%$ \\
\hline $\begin{array}{l}\text { Knowledge is captured in a very chaotic way } \\
\text { which hampers its accessibility. }\end{array}$ & $34 \%$ & $46 \%$ & $41 \%$ \\
\hline \multicolumn{4}{|l|}{ Knowledge sharing } \\
\hline $\begin{array}{l}\text { Knowledge is shared sufficiently among } \\
\text { employees in our office/department. }\end{array}$ & $76 \%$ & $56 \%$ & $63 \%$ \\
\hline $\begin{array}{l}\text { Key information is stored only in the PCs of } \\
\text { individual employees and is not shared. }\end{array}$ & $45 \%$ & $46 \%$ & $30 \%$ \\
\hline $\begin{array}{l}\text { Employees are sufficiently motivated to } \\
\text { share their knowledge with others. }\end{array}$ & $69 \%$ & $53 \%$ & $59 \%$ \\
\hline
\end{tabular}

Source: own research

Table 8 indicates that the size of an office may have positive as well as negative effects on KM practices. The larger the office, the more instruments are utilized. On the other hand, the larger the office the more chaotic was the capture of knowledge, as perceived by the respondents in the survey. Although a majority of respondents were satisfied with the level of knowledge-sharing among employees in their offices, a relatively high number stated that important key knowledge is accessible only 
via the PCs of other individual employees and is therefore not, in fact, "shared". This may be derived from an insufficient use of the intranet. Although the in-house intranet has become a common instrument, the survey indicated that larger offices did not often employ the intranet to make the following documents accessible to employees: internal magazine for employees; working materials for individual departments; databases with which departments work; instant messaging instruments. No thread of knowledge-sharing was disclosed in the survey. Employees did not feel they had to share their knowledge, largely because they did not trust their colleagues in the light of what might happen in the future - "Will I become expendable?", etc. Thus, the practical problem involves not only the technical means of sharing knowledge/experience, but an understanding of how to build it up, i.e. convey knowledge properly, to be able to apply it correctly.

It has also been suggested that fragmentation of the information systems in general, rather than lack or misuse of the intranet, has led to the current state of affairs. Individual modules of the information system work independently (i.e. accounting, budgeting and personnel), while failing to become integrated into a single system overseen by a BI superstructure that would, by way of a "managerial dashboard", display key information for future employees. This a trend that has, in recent years, come to spread through larger- and medium-sized cities.

\section{Discussion}

In early 1993, Laurence Prusak, together with a number of colleagues, organized a conference in Boston especially devoted to KM. This could well be considered the beginning of the KM timeline. One of its main targets was to define "organizational knowledge" in order to differentiate it from data and information. According to Prusak (2001), it was felt that even perfectly managed information would not lead to greatly improved productivity and innovation in firms. In his article "Where did knowledge management come from" Prusak (ibid.) points out that, at the time, KM was one response to "globalization, ubiquitous computing and a knowledge-centric view of the firm" (1002).

To address the results of the empirical investigations herein, the last paragraph of Prusak's article (ibid.), i.e. "The past and the future" (of KM) (1006) is a good starting point. Here, he pointed out that KM may (as of the time of publication) follow one of two possible future paths:

1. The better one, Prusak maintained, would be the direction taken by the quality movement, $c f$. quality management in the wake of, for instance, Edward Deming (Deming 1993; Deming 1986). Over time, this became an integral element of organizational effectiveness. Prusak hoped that KM, in similar fashion, would become so thoroughly integrated that it would eventually become invisible. 
2. A less appealing path, he considered, would be similar to that taken by re-engineering. Re-engineering, according to Prusak - by way of its misapplications - had became a byword for crude reductionist downsizing that in fact did a great deal of harm. And this, he pointed out, could happen to KM, considered by some as merely yet another kind of "hype".

The empirical investigation herein definitely, though perhaps indirectly, addresses both possibilities. In future research, the authors will attempt to follow Prusak in his quest to keep KM on a better path and thus support - by reinterpreting the empirical findings herein and by arguing theoretically - Prusak's plea that tolerance for ambiguity and complexity be maintained as well as the rigour that should define the best version of KM to strive for.

Independently of the Boston conference in 1993, in 1995 an English-language version of an approach to KM, by Nonaka and Takeuchi, was published. It contained the already well-known SECI model (socialization - externalization - combination - internalization) of knowledge production widely discussed and used in KM. However, before going on to touch upon the different generations of KM, it must be stressed that the Japanese approach - taking up Michael Polanyi's idea of tacit knowledge (Polanyi 1966) - rested upon a different conception of knowledge, well-explicated in Andriessen (2008). This is essential insofar as in this empirical investigation one is led to the impression that administrative officers still believe - which is essential for the interpretation of the empirical results concerning their attitudes - that knowledge as such can be documented and explicated in a comprehensive way. In the West, the Japanese approach thus initiated the idea that KM was primarily the use of databases ("first-generation" KM) for a complete "documentation" of relevant knowledge. This is, incidentally, not true of the original idea of tacit knowledge to be found in Polanyi (1966). To correct this misunderstanding in the West, it is necessary to incorporate semantics ("second-generation" KM, cf., for instance, knowledge life-cycles as per Firestone and McElroy 2003) and pragmatics ("third-generation" KM, cf., for instance, value networks as per Allee 2003, a promising approach, although other techniques of capturing and conveying knowledge to reproduce, for example, economic success, are also in use).

The authors are also aware that in order to understand the kind of consciousness of KM, or KM instruments existing and used in public administration, it appears inadequate, as in re-engineering (Hammer and Champy 1993), to investigate just the "instruments" considered responsible for success. Such positive outcomes may be understood either as economic or as the implementation of administrative routines to bring administrative decisions into operation. In KM these instruments, actualized in certain processes, would be the identification, capture, storing and sharing of knowledge. The knowledge provided is then considered to be responsible for successful administrative behaviour. This idea links up with Herbert Simon's concept of "satisficing" (Simon 1947) - sifting available alternatives until an accept- 
ability threshold is met - in the realization of decisions. This is a consideration for further research addressing the actual influence of knowledge when administrative decisions may be at stake.

To see the problem of using $\mathrm{KM}$ as a tool in the context of public administration and self-governance, one has also to reconsider the origin of KM, to turn at least to the seminal book by Nonaka and Takeuchi (1995). Their first point was actually to "explain" the success of Japanese firms in terms of the SECI model of knowledge creation and, as a second step, it could also be understood as a process model to guide our actions in trying to reproduce an envisioned success, economic or otherwise. However, if the SECI model is to be seen as a process model for KM in the context of public administration and self-governance - that is identifying (externalizing/capturing), combining (modelling/storing), internalizing and finally sharing/socializing knowledge - what counts as success, in contradistinction from the original Japanese context, must be established, i.e. in the context of public administration. "Routines" might be disclosed that rest upon the application of experience and knowledge to reproduce the success anticipated. The latter not only comprises making the best use of finance, but also public acceptance of actions, as far as "problem solutions in society" are in play. Thus, the missing consciousness of knowledge usage both as a means of support in applying routines properly, as well as a means of correction to facilitate understanding of the limits of the proposed or reconstructed practical solutions in the context of public administration, might indicate that we are mistaken and distracted if we think that $\mathrm{KM}$ is useless in public administration.

Finally, turning to the infamous lessons from business process re-engineering, and Prusak's unwillingness to fall into that particular trap (Prusak 2001), it is essential to understand that, both for experimental and theoretical reasons, we cannot reduce real-life practice of self-government and public administration to a set of algorithmic routines, to be actualized by lay people working at an assembly line, to produce solutions. One only needs to compare the early business ideas or models of Ford (Taylor 1919) with the practice of Toyota (Osono et al. 2008). What was lost in the case of Ford was any "knowledge of correction", on the part of both engineers and practitioners, in proper communication. One might even go as far as to argue - theoretically, but also considering or explaining practical experiences - that any algorithms or sets of administrative rules intending to reproduce self-governance success should take over routines from our daily work and thus produce leeway for creativity, innovation and sensitivity to the future. There are certainly good practical examples and techniques of how to achieve this (e.g. Hamel 2012; Rifkin 2014; Gatarik and Born, forthcoming). In practice, we need, in contrast to the re-engineering approach, to foster communication, cooperation and trust, as Elinor Ostrom pointed out in her 2009 Nobel Prize speech when she spoke of commons and their important role in modern society. This links up with the idea of "knowledge as a commons" (Hess and Ostrom 2007; Frischmann et al. 2014). A further theoretical 
foundation relevant in this context may be found in "SuperCooperators" by Nowak and Highfield (2011) in connecting biology and game theory to economics.

\section{Conclusions and further research directions}

This contribution summarizes and discusses selected findings of a survey of KM practices in Czech self-governments. The authors are aware that the article is somewhat descriptive. There was a serious undertaking to guarantee anonymity for respondents to the survey, and sorting questions were employed, as introduced in the Methodology section. Nevertheless, a number of interesting observations emerged. Although the survey did not provide representative data, it indicates that KM is quite underdeveloped as well as undervalued in the Czech Republic. Clearly, KM seldom features among the priorities of municipal and regional offices and is often perceived as a useless, annoying burden. The survey disclosed a number of contradictions that must be addressed in the future (e.g. KM is perceived as useless although managers have sufficient awareness and knowledge of KM according to the respondents; knowledge is shared sufficiently according to respondents but a similar percentage of them state that key knowledge is accessible only on the PCs of individual employees and is not automatically shared, etc.).

Furthermore, the survey approach selected for the study may appear to presuppose an implicit assumption that leads to questions centring around whether people naturally use certain KM techniques such as "identification, capture, storage and sharing" in practice, that is, reflectively, to explain their actions, such as decisions regarding a meaningful allocation of financial or other resources. One may gather the impression that they are aware of the question of whether they are using $\mathrm{KM}$ technique in their practice. Of course, thinking about doing something is not necessarily doing that thing, whatever people say about themselves. In this light, building decisions about implementing, for instance, $\mathrm{KM}$ in public administration upon these kinds of investigation could prove highly problematic, i.e. if they are taken at face value. However, this only leads to further possibilities of interpretation of these research results.

The results herein point towards the necessity of introducing KM techniques in order to grasp knowledge that may improve performance based on specific KM guidelines, but much depends on both empirical and theoretical considerations about $\mathrm{KM}$ in general. What is $\mathrm{KM}$ about in the first place? How does it work and improve organizational performance? It would also have to include meticulous enquiry into how to superimpose it upon the various contexts of public administration.

So, what is KM really about? Which problems is it, or was it, intended to solve? How should it be implemented or installed (in any kind of practice)? The starting point for KM at the practical level of life may be seen as "trying to reproduce 
(economic) success with the aid of (teachable) rules or routines", together with the realization that these must evolve out of the particular matter in hand. In practical terms, however, it is essential that these rules or routines be invented either by the people who found out or created some acceptable solution, or by those who want to explain the way in which those solutions work and understand where such rules came from. Once these rules are established they must reasonably be expected to be useable even by people with "little experience" in the field of interest.

Theoretically speaking, one problem is that simply following or applying the rules or routines does not always produce the results originally in mind, i.e. an extra "evaluation" of the results must always be on the cards. But who should judge? Trusting in the correct application of the rules may not be enough (cf. the problem of following rules discussed in Wittgenstein 1953). Thus, we need "knowledge of/for correction" unless we believe the rule systems are intrinsically complete and all the necessary knowledge is contained within, or encompassed by, the rules (cf. the discussion of the incompleteness of formal systems by Gödel 1931). One may, therefore, ask: Can a set of techniques to identify or construct the knowledge necessary to prevent misuse of any given routines, rules or algorithms be invented or introduced as part of $\mathrm{KM}$ ?

Even if we confine ourselves to considering and learning the techniques required to capture the relevant knowledge (e.g. knowledge of correction) and the different "epistemic resolution levels" of people, we can never be sure whether this is enough. To put this in terms currently controversial in definitions of "science", we cannot simply identify with the "ideal of physics" and take to physical instruments and formulae to measure success. In order to apply KM appropriately, we need to understand the "solution" KM should provide in a more abstract way. Many of the tasks of administrative officers or people working in public administration concern decisions about the allocation of resources and applying routines or rules in order to reach or generate a solution or decision that suggests specific actions that may achieve well-accepted aims. Thus we need to visualize the situations and manners of the application of rules. The problem is that - arising out of practice - established knowledge already exists of both the application of routines and the evaluation of the results of such application of routines. The more one knows and can communicate, especially in situations verging on the dangerous (consider High Reliability Organizations, see Weick and Sutcliffe 2015), the more intuitions based upon experience and expertise of corrections are available (this does not, of course, mean these intuitions do not occasionally stray from the ideal, by any means). As in many similar cases, this undocumented knowledge of evaluation and correction should be made available, especially via case-sensitive explanatory documentation. However, this still remains in the realms of the ideal: how are administrative officers then to learn to use these records properly? 
The real problem might be to understand that people with expertise have "extra knowledge" or "experience" of generating solutions and applying selected routines, as well as of evaluating the results of the application of such routines. Future research could, therefore, ask whether it is possible to actualize techniques both for grasping/documenting and communicating and instantiating the "corrective knowledge" available to experienced administrative officers in such a way that a set of rules or routines plus some sort of universal common sense - folk knowledge are sufficient for success. Experience from other fields (perhaps teaching physics, where general relativity changed paradigms so profoundly) suggests that it is essential to enrich or change individual folk knowledge. One need look no further than what happened in "classical" physics and the concepts of inertia and force arising out of Galileo and Newton.

\section{Acknowledgements}

This paper was enabled as part of research carried out within the TAČR project "Knowledge Management in Local and Regional Development" (TB040MMR008).

\section{References}

Alavi, M. and D. E. Leidner. 2001. "Knowledge Management and Knowledge Management Systems: Conceptual Foundations and Research Issues." MIS Quarterly 25(1), 107-136.

Allee, V. 2003. The Future of Knowledge: Increasing Prosperity Through Value Networks. Amsterdam et al.: Routledge.

Ammons, D. N. and D. J. Roenigk. 2015. "Performance Management in Local Government: Is Practice Influenced by Doctrine?” Public Performance \& Management Review 38(3), 514-541.

Andriessen, D. G. 2008. "Stuff or Love? How Metaphors Direct our Efforts to Manage Knowledge in Organizations." Knowledge Management Research \& Practice 6(1), 5-12.

Bolisani, E. and M. Handzic (eds). 2015. Advances in Knowledge Management: Celebrating Twenty Years of Research and Practice. Heidelberg: Springer.

Burford, S. and S. Ferguson. 2009. "Managing Knowledge by Intention: The Role of Standards, Frameworks and Models." Actkm Online Journal of Knowledge Management 5(1), 3-14.

Cong, X. and K. V. Pandya. 2003. "Issues of Knowledge Management in the Public Sector." Academic Conferences Limited, http://www.ejkm.com/issue/download.html?idArticle=17 (accessed June 1, 2017). 
Deming, W. E. 1986. Out of the Crisis. Cambridge, MA: MIT Center for Advanced Engineering Study.

Deming, W. E. 1993. The New Economics for Industry, Government, Education. Cambridge, MA: MIT Center for Advanced Engineering Study.

Edwards, J. S. 2015. "Knowledge Management Concepts and Models." In Bolisani, E. and Handzic, M. (eds.). Advances in Knowledge Management: Celebrating Twenty Years of Research and Practice. Heidelberg: Springer, 25-44.

Farzin, M. R. et al. 2014. "A Survey of Critical Success Factors for Strategic Knowledge Management Implementation: Applications for Service Sector." Procedia: Social and Behavioural Sciences 109, 595-599.

Ferguson, S. 2006. "AS 5037-2005: Knowledge Management Blueprint for Australian Organisations?" The Australian Library Journal 55(3), 196-209.

Firestone, J. M. and M. W. McElroy. 2003. Key Issues in the New Knowledge Management. Amsterdam et al.: Routledge.

Frischmann, B. M, M. J. Madison and K. J. Strandburg (eds). 2014. Governing Knowledge Commons. Oxford: Oxford University Press.

Gatarik, E. 2014. "The Many Faces of 'Innovation Ecosystems': Investigating and Reflecting the Ecology of Decision-Making as Core of the Topic." IFKAD 2014, 1887-1906.

Gatarik, E. and R. Born. 2012. "The Practice of Network Economics as a Competitive Advantage of Regions and Societies." IFKAD - KCWS 2012, 2143-2166.

Gatarik, E. and R. Born. 2015. "Managing Network Economies: The Competitive Advantage of Commons as Ecosystems of Innovation." Journal of Organisational Transformation and Social Change 12(3), 287-307.

Gatarik, E. and R. Born. (forthcoming). "Innovating for Organisational Resilience: An Epistemological Investigation into Business Continuity Practice in an Austrian SME." Journal of Organisational Transformation and Social Change VOL.

Gödel, K. 1931. "Über formal unentscheidbare Sätze der Principia Mathematica und verwandter Systeme I." Monatshefte für Mathematik und Physik 38(1), $173-198$

Hamel, G. 2012. What Matters Now: How to Win in a World of Relentless Change, Ferocious Competition and Unstoppable Innovation. Hoboken: Wiley.

Hammer, M. and J. Champy. 1993. Reengineering the Corporation: Manifesto for Business Revolution. New York: Harper Collins. 
Hammerschmid, G., S. Van de Walle and V. Stimac. 2013. "Internal and External Use of Performance Information in Public Organizations: Results from an International Survey." Public Money \& Management 33(4), 261-268.

Handzic, M. A. 2015. "Descriptive Analysis of Knowledge Management Research: Period from 1997 to 2012." In Bolisani, E. and Handzic, M. (eds.). Advances in Knowledge Management: Celebrating Twenty Years of Research and Practice. Heidelberg: Springer, 45-66.

Hasan, H. M. 2004. Bottling Fog: Conjuring up the Australian KM Standard. Research Online. University of Wollongong. Available online at: http://ro.uow. edu.au/cgi/viewcontent.cgi?article $=1360 \&$ context $=$ commpapers $\quad$ (accessed June 1, 2017).

Hess, C. and E. Ostrom (eds). 2007. Understanding Knowledge as a Commons: From Theory to Practice. Cambridge, MA: MIT Press, 41-81.

Klimovský, D. et al. 2014. "Inter-Municipal Cooperation in Lithuania and Slovakia: Does Size Structure Matter?” Lex Localis: Journal of Local Self-Government 12(3), 643-658.

Martin, J. and A. Spano. 2015. "From Performance Management to Strategic Local Government Leadership: Lessons from Different Cultural Settings." Public Money \& Management 35(4), 303-309.

Matejova, L. et al. 2015. "Political Business Cycle in Local Government: Case Study of Czech Municipalities." In Matejova, L. and Spalkova, D. (eds.). Proceedings of the $19^{\text {th }}$ International Conference: Current Trends in Public Sector Research. Brno: Masarykova Univerzita, 142-148.

Nam, T. and T. A. Pardo. 2011. "Conceptualizing Smart City with Dimensions of Technology, People, and Institutions." In Proceedings of the $12^{\text {th }}$ Annual International Conference on Digital Government Research. Also available at: https://inta-aivn.org/images/cc/Urbanism/background\%20documents/ dgo_2011_smartcity.pdf (accessed June 1, 2017).

Němec, J., B. Mikušová Meričková and M. Svidroňová. 2015a. "Co-Creation in Local Public Services Delivery Innovation: Slovak Experience." Lex Localis: Journal of Local Self-Government 13(3), 521-535.

Němec, J., B. Mikušová Meričková and M. Svidroňová. 2015b. "Social Innovations in Public Services: Co-Creation in Slovakia." In Schoburgh, E. and Ryan, R. (eds.). Sborník z mezinárodního vědeckého semináře: Current Trends in Public Sector Research Xix. Brno: Ekonomicko, Správní Fakulta, 273-281.

Nielsen, P. A. 2014. "Learning from Performance Feedback: Performance Information, Aspiration Levels, and Managerial Priorities." Public Administration 92(1), 142-160. 
Nonaka, I. and H. Takeuchi. 1995. The Knowledge-Creating Company: How Japanese Companies Create the Dynamics of Innovation. Oxford, UK: Oxford University Press.

Nowak, M. and R. Highfield. 2011. Supercooperators: Altruism, Evolution, and Why We Need Each Other to Succeed. New York: Simon and Schuster.

Osono, E., N. Shimizu and H. Takeuchi. 2008. Extreme Toyota: Radical Contradictions that Drive Success at the World's Best Manufacturer. Hoboken: Wiley.

Ostrom, E. 2009. "Beyond Markets and States: Polycentric Governance of Complex Economic Systems" Nobel Prize lecture. Stockholm, Sweden: Nobel Media, 8 December 2009.

Plaček, M., F. Ochrana and M. Půček. 2015. "Benchmarking in Czech Higher Education: The Case of Schools of Economics." Journal of Higher Education Policy and Management 37(4), 374-384.

Plaček, M., M. Půček and F. Ochrana. 2016. "Political Business Cycle in the Czech Republic: Case of Municipalities." Prague Economic Papers 25(3), 304-320.

Plaček, M., M. Schmidt, F. Ochrana et al. 2016. "Impact of Selected Factors regarding the Efficiency of Public Procurement (The Case of the Czech Republic) with an Emphasis on Decentralization." Ekonomický Časopis 64(1), 22-36.

Polanyi, M. 1966. The Tacit Dimension. Gloucester, MA: Peter Smith.

Prusak, L. 2001. "Where did Knowledge Management Come from?" IBM Systems Journal 40(4), 1002-1007.

Rifkin, J. 2014. The Zero Marginal Cost Society: The Internet of Things, the Collaborative Commons, and the Eclipse of Capitalism. New York: Macmillan.

Simon, H. A. 1947. Administrative Behavior: A Study of the Decision-making Processes in Administrative Organization. New York: Macmillan.

Špaček, D. 2015. "Quality Management in the Czech Public Administration." In Vries, M. and Nemec, J. (eds.). Implementation of New Public Management Tools: Experiences from Transition and Emerging Countries. Bruxelles: Bruylant, 285-304.

Špaček, D. 2016. "Knowledge Management in Public Administration and Research in the Czech Republic: Preliminary Findings." In Matějová, L. and Špalková, D. (eds.). Proceedings of the $20^{\text {th }}$ International Conference Current Trends in Public Sector Research. Brno: Ekonomicko-správní fakulta, 94-101.

Spender, J. C. 2015. "Knowledge Management: Origins, History, and Development." In Bolisani, E. and Handzic, M. (eds.). Advances in Knowledge Management: Celebrating Twenty Years of Research and Practice. Heidelberg: Springer, 3-24. 
The NisPacee Journal of Public Administration and Policy, Vol. X, No. 1, Summer 2017

Taylor, F. W. 1919. The Principles of Scientific Management. New York: Harper \& Brothers.

Weick, K. E. and K. M. Sutcliffe. 2015. Managing the Unexpected: Sustained Performance in a Complex World. Hoboken: Wiley.

Wittgenstein, L. 1953. Philosophical Investigations. Oxford: Basil Blackwell. 